\title{
Natural Determinant Stimuli and Agroforestry Benefit Stimuli for Developing Medical Agro-Industry of Kerinci Society in Sebelat Kerinci National Park
}

\author{
Mustopa Marli Batubara \\ Agribusiness Departement, Agriculture Faculty \\ University of Muhammadiyah Palembang, Indonesia \\ E-mail: Mustopa_marli@yahoo.com
}

$\begin{array}{lcc}\text { Received: January 5, } 2017 & \text { Accepted: February 15, } 2017 \quad \text { Published: March 26, } 2017 \\ \text { doi:10.5296/jas.v5i1.10991 } & \text { URL: https://doi.org/10.5296/jas.v5i1.10991 }\end{array}$

\begin{abstract}
Natural and benefit stimulus are important in doing the conservation action in order to achieve the conservation goals. Kerinci community who live in the Kerinci Sebelat National Park showed the activities of agroforestry in natural and benefits stimuli. The result showed that there were seven plants that could be done by using agroforestry way of planting called pelak. They are cinnamon, coffee/ kawa, ginger, durian, mangosteen, potatoes and corn which indicated the medication content with the highest cultural values. Next, Those seven plants can be used as the raw material of the natural agro-industry medication to increase the society's income. The society of Kerinci get used to use those plants to cure diseases such as dysentery, rheumatic, diarrhea, flu, stomached, heart disease, back pain, chest pain, fever, colds, appetite problem, wound, fever, bleeding gums, burns, diabetes, blood pressure problems, and as antidote.
\end{abstract}

Keywords: Medicinal plants, Phytochemical test, Agro-industry natural medicine

\section{Introduction}

Indonesia is the one of megabiodiversity countries for medicinal and aromatic plants in the world. Besides having high diversity of medicinal plant, also has a cultural diversity shown by various tribes that inhabit it. Each tribe has a distinctive knowledge systems in managing biodiversity and the surrounding environment.

According to the national socio-economic survey in 2001, 57.7 percent of Indonesian community treat theirself without medical assistance, 31.7 percent of them use traditional medicinal plants and 9.8 percent choose other traditional treatments. Indonesia has a culture 
of traditional medicine included the use of medicinal plants since the first and preserved for generations. Region of forest cover change to other uses, causes the medicinal plants are also increasingly difficult to obtain. This can cause the loss of knowledge of gathering on the community that need to do a study.

One of that Indonesian societies is the Kerinci's tribe who live in iKerinci Regency Jambi Province. Kerinci community or uhang kincai is belong of tribes who have a life philosophy, as same as the Minangkabau ethnic community who have a philosophy of 'alam takambang jadi guru' (it means nature expand used as teacher). Kerinci community knowledge to the natural environment and its natural resources can be seen from how they regulate the use of the environment units and its resources (Aumeeruddy 2000). Aumeeruddy \& Bakels (1994) stated that Kerinci community know the forms of the environment units and know well how each function use. The changing of environmental unit through the adaptation process that persisted for generations to become a form of knowledge that they use.

Kerinci community already have the knowledge of how to exploit the forest and its produces such as plants and animals in it. Forest plants are used for food source, medicines, shelter and others. Animals who living in it also used as a food source and medicines. Harvesting of forest products is regulated by customary law applicable.

Batubara, M.M and Asvic Helidah (2016) showed that agroforestry activities is already natural and benefit stimuli for Kerinci community. The results showed there are 27 species of plants with cinnamon (Cinnamomun burmanii) have the highest ICS and INP in the amount of 67 and 43, which means cinnamon is essential in culturally and ecosystems. Farmers know cinnamon's bioecology as a basis for selecting the type and the production may improve farmers' prosperity to become community's benefit stimuli in doing agroforestry farming systems "pelak". Furthermore, in research on natural and benefits stimuli of agroforestry to increase prosperity Kerinci community has resulted in several types of plants were selected and superior for people because it has a high cultural values. Among those species have use as a medicinal plant, so we need further study on various types of useful plants as herbs then do its phytochemical analysis.

Community's basic knowledge in the Sebelat Kerinci National Park area main income is from Agroforestry plant "Pelak", thus it is developed with the vertical diversification to agro-industrial activities. Agro-industrial have a role as intermediate demand strength in developing agriculture. According to Suryana, et al. (1985) the development of agro-industries able to foster the industry's growth impartial rural economy, increase additional value and employment. Because of the identification of medicinal plants from Pelak plant Kerinci community could be developed natural medicine industry which is expected to have implications for farmers' productivity and income.

\section{Formulation of the Problems}

Based on the background stated, the local knowledge of Kerinci community to medicinal plants is a national asset that have very strategic for developing of medicinal plants into medicines and traditional herb, but its existence is on the wane in nature and that knowledge 


\section{Macrothink}

disappears concomitant leseening the extensive tropical forest in the area of Kerinci Seblat National Park area.

So based on this background, the formulation of the problem of this research are:

1. What are the photochemistry plant contents in the Kerinci community that used as the medicinal plant?

2. What do the Kerinci community usually do with the agroforestry plants as a natural medicinal plant?

\section{Obejctives of the Problems}

The objectives of this research are :

1. To identify the photochemistry plant contents in the Kerinci community which are used as the medicinal plant.

2. To know the Kerinci society's custom in using the agroforestry plant as the natural medicinal plants.

\section{The Urgency of the Research}

This research must be carried out to determine the types of plants that are useful as a medicinal plant and a treatment that can be developed as agroindustry of the natural medicine for treatment.

\section{Literature Review}

\subsection{Natural and Benefits Stimuli}

Improvement of prosperity Kerinci gained from managing agroforestry systems. It is because there is an assumption that the charateristic of bioecology (natural stimuli) and benefits (benefits stimuli) would be perceived by people in economic, ecology and socio-cultural. Natural and benefits stimulus of agroforestry systems that exist in Kerinci community. As stated by Zuhud (2007) that the prerequisite for the realization of the concept of tri stimulus amar conservation are (1) intended for the local community specific and unique is the community that has worked interact with forests and natural resources in local daily life and even have own their local knowledge from generation to generation of bio-resources are, (2) access rights, ownership rights, rights to harvest and right to utilize biological resources as in item 1 above shall be clear and (3) there must be continuity of local knowledge from the older generation to the younger generation.

\subsection{Agroforestry in the Kerinci Community Style}

Simply, agroforestry is the unities of conventional that consist of a small number of elements, a combination of element trees that have economic roles such as rubber (Havea braziliensis), Coconut (Coccus nucifera), clove, teak (Tectona grandis), or something that have a role in ecology such as dadap (flowering trees of Erythrina spp), kedawung (Parkia timoriana) and petai chinese with annuals crops such as rice plant, corn, vegetables or other crops such as 
bananas, coffee, chocolate and so on, which also have economic value (Michon et al. 2000).

Agroforestry is also interpreted as a method of optimal land use by combining the biological production system that rotates the short and long term on a sustainable basis simultaneously or sequentially in a forest area or outside it with the aim to improve the community's prosperity. Another definition states that agroforestry is a collective name for the land use's systems and technology where perennials (trees, shrubs, types of fern, bamboo, etc.) are planted along with crops and/ or animals with a particular goal in a form of spatial arrangement or temporal sequence and there are interactions between ecology and economy in it of the various components that may concern (Kartasubrata 2003).

According to this definition of agroforestry systems include interval variations at large and classified based on the following criterias:

a. Structural basis which involves the composition of components

b. Functional basis which involves the main functions and role of the system, especially wood.

c. Economics basis is regarding to the level of input in the management or the intensity and the scale of a management or business purposes (subsystems, commercial or intermider).

d. Ecology basis is regarding to the environment and compatibility of ecologicy and system.

Complexly, agroforestry could be defined as systems that consist of a large number of trees, shrubs, seasonal crops or grass' element. Physical appearance and dynamics in it is similar with natural primary and secondary forest ecosystems. Agroforestry systems complex are not forests which laid out slowly through the transformation ecosystems naturally, but it is the gardens which planted through the cultivation process. Agroforestry gardens are built on the lands that were previously clear away then planted and did an enrichment. Under of limited space conditions due to the increase and population growth as well as expansion of the logging concessions, transmigration and commercial plantation forestry, land that remaining mostly has been in the form of agroforestry.

Agroforestry is a management system's land that could be applied to agriculture and forests as a result of the food insecurity situation of the various regions in Indonesia. Deforestation and ecological degradation in tropical regions continued to spread, energy crisis and the result as the growing pressure of population growth (Nair, 1993). Furthermore, Nair said that agroforestry systems by local community are regarded to have the ability to fulfill the function of ecology, economic and social-cultural.

Agroforestry Kerinci community has long existed, known as fields and pelak. The fields are agroforestry systems with the cycle of cultivation of trees alternate with seasonal plants, while pelak is agro-forestry complex system with the main components of cinnamon or coffee, combined with various tree species from forest. The stages of pelak or fields activities are (1) During the first two years, annual crops grown with coffee and cinnamon, (2) Coffee production is generally up around to eight years, after that years the farmers have three choices which produce three systems as (1) system 1 (field) that is felled and harvested 
cinnamon, coffee trimmed short and annual crops are planted so that the system back to stage 1; (2) System 2 (field): cinnamon maintained and cared continuously around the 25th years, cinnamon is cutted and harvested, then the system back to stage 1; (3) System 3 (pelak) that is the types of useful trees that have been planted or growing spontaneously during phase 1 and 2 cinnamon maintained together so that the system becomes a permanent mixed plantation or pelak agroforestry.

\subsection{Medicinal Plants}

Medicinal plants is a whole species of plants that are known have medicinal properties that can be grouped into traditional, modern, and potential medicinal plants. Medicinal plants have been used by the Indonesian people since hundreds years ago. The experience of our ancestors in the gathering herbs for traditional medicine has been passed down from generation to generation (Zuhud, 2007).

There are tropical forests around $30.000-40.000$ species of flowering plants in Indonesia, an amount that exceeds with other tropical regions in the world such as South America and West Africa. Based on the research that have been done until 2010 that is found as many as 1,845 species of medicinal plants are scattered in various forest formations and other nature ecosystems. These circumstances make Indonesia as the one of the world's origins of biodiversity importance. Diversity of medicinal plants collected in different Indonesia forest formations is a national asset that is invaluable of human prosperity

Since the beginning of civilization in worldwide, human used plants as medicine. The ancestors of the Egyptians using Syacamore tree, oil of cedar tree and oil of Camomile. Mesopotamian use castor oil, mirh, secar, terpentine, hanbane, asafetida, mint, Popy, fig and mandrake. Indian healers have known nearly 1,000 medicinal plants include of sedatives rauwolfia. China also has a medicinal plant Chaulmogra which used leprosia, long time before known by people in Europe (Pei et al., 2009).

According to Purwanto (2004) for the Indonesian people in rural area, isolated and living in the surrounding forest, the utilization of medicinal plants for their health is not new, but has happened for long time. It was also stated that each tribe has a specificity in the gathering and use the plants as medicine and herbs, depending on the level of cultural and environmental resources of the surrounding nature. Zuhud (2007) also stated that in various parts of the world, the disease and its treatment method already has a typical system, different from each other, the nature and the judgment are appropriate with diversity of the place (natural resources and human culture), the time and circumstances. In the atmosphere of the disease and its treatment has been the character of the nation.

\subsection{Phytochemicals}

Generally, there are a lot of knowledge of the local population related to the surrounding plants as medicines. This knowledge would be recorded and samples would be taken for bioactive chemical analysis. To determine the content of bioactive components that present in the plants is done by phytochemical screening. Phytochemical screening is intended as a preliminary research to determine the type of substance content of a certain plant and classify 
the important compounds for instance alkaloids, saponins, terpenes and so on by using the reagents specific to each groups. The content of bioactive components produced from the secondary metabolism on plants in the nature that are influenced by the intrinsic and extrinsic factors (Shukla et al.2006).

According to Manitto (1981) bioactive substances are biologically active compounds produced by plants through the secondary metabolism process. Bioactive substances are natural materials that formed the most important in living organisms through secondary metabolic processes. Primary metabolism are relatively similar in terms of structure and contained in most plants, secondary metabolites are usually responsible for the characteristic of smell, color, taste and medical plants' need. Although some of the compounds are waste product of physiological processes, most of these secondary metabolites help plants adapt to their environment, competition with other plants, keep the plants from insects or other animals or attract other organisms that play a role in flowering, fruit or spread of plant protection.

\subsection{Agro-industrial Development}

Agro-industrial development is the beginning of the non-agricultural activities (industries) development in rural areas. Because of this understanding, we can further understand the role of industry in employment in the village and city. The development of agro-industries have dimensions in increased productivity, income, employment and income distribution. Furthermore, consumption patterns and the structure of rural community will also diversify (Ahmad Suryana, et al. 1995).

\section{Method of the Research}

\subsection{Location and Time of the Research}

This research has been conducted in the village of Keluru Kecamatan Keliling Danau Kerinci Regency in Jambi province to get the kinds of plants that are useful as a medicinal plant. Retrieval of the data held for two months from February to April 2014. While for the phytochemical test held in the laboratory of phytochemical Institut Pertanian Bogor 2015.

\subsection{Collecting of the Data}

Primary data from Keluru Kecamatan Keliling Danau Kerinci Regency in Jambi Province was taken to identify the species composition of the plant "pelak" by recording all the types of plants that are found in the pelak area of Keluru Kecamatan Keliling Danau Kerinci Regency in Jambi. Then, identify all species of composition pelak plant that useful as a medicinal plant. To be examined and the benefits of its phytochemical test. Phytochemical research was conducted to determine the content of medicinal plants used by Kerinci community. Phytochemical test done for herbs that are selected based on predetermined criteria. The implementation of phytochemical test include: alkaloids test, test steroids/ triterpenoids, test phenolic compounds/ flavonoids, test saponins, flavonoids and tannins. Besides, the farmers were also interviewed in order to know their strategy in using the agroforestry product as the raw material for natural medicinal industry. 


\subsection{Analysis of the Data}

Analysis of the data has the characteristic as qualitative and quantitative. Qualitative data is creating a matrix of data in the form of plant species that have utility as a medicinal plant that used as the basis of analysis as a means of data grouping as the calculating basis. While quantitative data is intended as a complement and support the qualitative data that has been collected by calculating the value of cultural importance (Index of Cultural Significance = ICS) referenced from Turner (1988) and The Importance Value Index (IVI) plant.

Index of Cultural Significance (Index of Cultural Significance = ICS) of each plant using a technique that developed by Turner (1988) modified by Purwanto (2007). Index of this cultural significance uses three components such as the quality of use, the intensity of use and the exclusivity of use with the following formula:

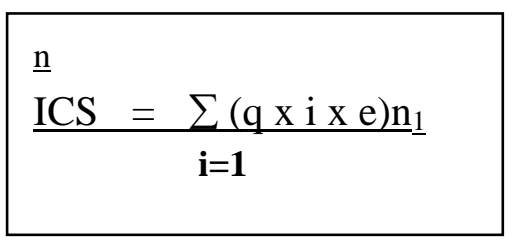

Because of each plant species has several uses, then the equation becomes as follows:

$$
\operatorname{ICS}=\left(q_{1} \times i_{1} \times e_{1}\right) n_{1}+\left(q_{2} \times i_{2} \times e_{2}\right) n_{2}+\ldots \ldots \ldots+\left(q_{n} \times i_{n} \times e_{n}\right) n_{n}
$$

Notes : ICS $=$ index of cultural significance $q=$ quality value, $i=$ intensity value, $e=$ exlusivity value , $\mathrm{n}=$ the use to

While the index of plant significance is the important value of plant ecologically which are calculated based on the relative density (KR), relative dominance (DR) and relative frequency (FR). The formula of index of plant significance is as follows: INP $=\mathrm{KR}+\mathrm{FR}+$ DR. Notes : INP $=$ index of significance Index, $\mathrm{KR}=$ Relative Density, FR $=$ Frequency Relative and DR = Dominance Relative.

Next, those plants that already tested to be the plants which have the cultural value were tested by using photochemistry (Alkaloid, Flavonoid, Triterpenoids, Steroid, Tannin and Saponin) to know the content of plant as medicinal plants. Quantitative data analysis was used to described the use of medicinal plants as the natural medication of Kerinci Society.

\section{Results and Discussion}

\subsection{The Composition of Pelak Plant of Kerinci Community}

Based on the results of this research identified as many as 27 species of plants that could be found in the area of pelak community. Types of crops grown by farmers generally consist of seasonal crops (horticulture) and perennial plants (tree species). Horticultural crops such as chili, cayenne pepper, corn, ginger/ spadeh, beans leatherback, green beans, kale, turmeric, squash, bitter groud, sweet potatoes, cabbage, carrots and potatoes. While the species of trees or perennial plants such as cinnamon, pecans, avocados, betel nut tree, surian, Kawo / coffee, mangosteen, durian, bamboo, benzoin, bachang and ambrarella (Batubara and Asvic 
Helida, 2016)

Pelak Plant of Kerinci community is identified as there are 15 species of 9 families that families are Solanaceae, Poaceae, Zingiberaceae, Fabaceae, Papilionaceae, Convolvulaceae, Cucurbitaceae, Brassicaceae and Apiaceae which chosen by Keluru community as horticulture crops. While annual plants consists of 12 species of plants from 12 families were planted, namely family Lauraceae, Euphorbiacea, Lauraceae, Arecaceae, Meliaceae, Rubiaceae, Graciniaceae, Bombacaceae, Poaceae, styracaceae, Verbenaceae and Burseraceae.

The selection of plants is influenced by several factors such as the market demand for these species, suitability factors with plant species and its growing and the factors of community knowledge based on the experience gained from the previous generation.

\subsection{Medicinal Plants Identification of Kerinci Community}

Based on the identification of 27 species of the utilization pelak plants of Kerinci community, there are 20 kinds (74\%) of plants which are useful as medicinal plants as follows: (Rudjiman, et al. 2003) and (Batubara and Asvic Helida, 2016).

1. Group habitat of shrubs, bushes, lianas. Herba is the plant

- Chilli (Capsicum annuum Linn)

- Cayenne pepper (Capsicum frutescens Linn)

- Corn (Zea mays Linn)

- Ginger (Zingiber officinale Roxb)

- Nuts starfruit (Psophocarpus tetragonolobus)

- Long Beans (Vigna cylindrical (L) .Skeels

- Peanut (Arachis hypogeal Linn)

- Kale (Ipomea aquatic Forsk)

- Turmeric (Curcuma domestica Val)

- Sweet potato (Ipomoea batatas Poir)

- Cabbage (Brassica oleracea)

- Carrots (Daucus Linn Corata)

- Potato (Solanum tuberasum Linn)

2. Group habitat of trees

- Cinnamon (Cinnamomum burmanii Nees)

- Avocado (Persea Americana Mill)

- Coffee / Kawo (Coffea arabica Linn)

- Mangosteen (Garcinia mangostana L)

- Durian (Durio zibethinus Murr)

- Bachang (Mangifera foetida L)

- Ambrarella (Spondias pinnata Soland Ex Park)

While based on the estimated of index of cultural significance (ICS) was obtained 67 plants to the highest ICS cinnamon (Cinnamomun burmanii Nees) and 6 for ICS low of kale 
(Ipomea aquatica Forsk) (Table 1).

Table 1.List of plants based on ICS scoring

\begin{tabular}{lllc}
\hline \multicolumn{1}{c}{ Local Name } & \multicolumn{1}{c}{ Scientific Name } & \multicolumn{1}{c}{ Famili } & ICS \\
\hline Cinnamon & Cinnamomum burmaniiNees & Lauraceae & 67 \\
Kawo/Coffee & Coffea arabica Linn & Rubiaceae & 32 \\
Ginger & Zingiber officinale Roxb & Zingiberaceae & 24 \\
Durian & Durio zibethinus & Bombacaceae & 24 \\
Mangosteen & Garcinia mangostana & Graciniaceae & 21 \\
Potato & Solanum tuberasum Linn & Solanaceae & 13 \\
Corn & Zea mays Linn & Poaceae & 12 \\
Peanut & Arachis hypogea Linn. & Fabaceaea & 12 \\
Turmeric & Curcuma domestica & Zingiberaceae & 12 \\
Avocado & Persea americana MILL & Lauraceae & 12 \\
Bachang & Mangifera foetida & Verbenaceae & 12 \\
Amrbarella & Spondias pinnata & Burseraceae & 12 \\
Chilli & Capsicum annum Linn. & Solanaceae & 9 \\
Cayenne pepper & Capsicum frutescens Linn & Solanaceae & 9 \\
Cabbage & Brassica oleracea & Brassicaceae & 9 \\
Carrot & Daucus carota Linn & Apiaceae & 9 \\
Nuts starfruit & Psophocarpus tetragonolobus & Fabaceaea & 8 \\
Long Beans & Vigna cylindrica (L.) Skeels & Papilionaceae & 8 \\
Sweet potato & Ipomoea batatas Poir. & Convolvulaceae & 8 \\
Kale & Ipomea aquatica Forsk. & Convolvulaceae & 6 \\
\hline
\end{tabular}

(Source: Batubara dan Asvic Helida, 2016)

Based on the estimated value of ICS in the range of 6-67 obtained there are seven highest species of cinnamon (67), coffee / kawa (32), ginger (24), durian (24), mangosteen (21), potatoes (13) and corn (12). These seventh species are those species that are already known by Kerinci community both natural and benefits. Natural knowledge includes Bioecology of those plants while benefits knowledge includes the category of the use and the characteristic of use (subsistence or commercial).

\subsection{Phytochemical Analysis}

Phytochemical analysis is a preliminary test to determine the presence of specific chemical compounds such as alkaloids, phenolic compounds, steroids, samponin and triterpenoids. This test is very useful to provide information on the type of chemical compounds found in plants. From the 27 species of pelak plants there are 20 species of plants that serve as a medicinal plant. The information as a medicinal plant was obtained from interviews with Keluru community and participant observation research in the field which was elaborated with the reference book of Plant Medicine Indonesia (2010). Based on the phytochemical studies conducted chemical content that derived from 20 species of that medicinal plants 
(Table 2).

Table 2. The Results of phytochemical analysis derived from the medicinal plant of pelak

\begin{tabular}{lcccccc}
\hline \multicolumn{1}{c}{ Local Name } & \multicolumn{5}{c}{ COMPONENT TEST } \\
\hline Chili & A & F & T & St & T & Sa \\
Cayenne pepepr & - & - & + & ++ & + & ++ \\
Corn & - & - & + & ++ & + & ++ \\
Ginger & ++ & + & - & ++ & ++ & + \\
Starfruit's nut & + & ++++ & + & +++ & + & - \\
Long Beans & - & ++ & - & +++ & + & ++ \\
Peanut & - & ++ & - & +++ & + & ++ \\
Kale & ++ & ++ & + & +++ & + & + \\
Turmeric & - & - & - & + & + & + \\
Sweet potato & - & ++++ & + & ++ & + & - \\
Cabbage & ++ & + & + & +++ & + & - \\
Carrot & + & + & + & +++ & - & - \\
Potato & + & + & ++ & +++ & - & ++ \\
Cinnamon & ++ & + & - & + & +++ & +++ \\
Avocado & ++ & ++ & +++ & +++ & ++++ & ++ \\
Kawo/Coffee & +++ & ++ & + & +++ & + & +++ \\
Mangosteen & +++ & +++ & + & +++ & + & ++ \\
Durian & +++ & +++ & + & +++ & + & - \\
Bachang & - & - & ++ & +++ & - & ++ \\
Ambrarella & ++ & + & ++ & + & - & - \\
\hline Note: A alkalo & ++ & - & + & + & + & + \\
\hline
\end{tabular}

Note $: \mathrm{A}=$ alkaloid, $\mathrm{F}=$ Flavanoid, $\mathrm{T}=$ Triterpenoid, $\mathrm{St}=$ Steroid, $\mathrm{T}=$ Tanin dan $\mathrm{Sa}=$ Saponin . Sign $(-)=$ not detection, Tanda $(+)=$ weak positive, $(++)=$ positive, Sign $(+++)=$ strong positive and sign $(++++)=$ versy strong positive.

Table 2 shows the results of phytochemical analysis of 20 kinds pelak that serves as a medicinal plant with the characteristics of the content that is not detected, weak positive, positive, strong and very strong positive (Table 3).

Table 3. Chemical contetnts of medicinal plants and the number of species that analyzed

\begin{tabular}{lrrrrrr}
\hline & \multicolumn{6}{c}{ Jumlah jenis/ kriteria } \\
\cline { 2 - 6 } \multicolumn{1}{c}{ Chemical } \\
\cline { 2 - 6 } & $\begin{array}{c}\text { Not } \\
\text { Detection } \\
(-)\end{array}$ & $\begin{array}{c}\text { Weak } \\
\text { Positive } \\
(+)\end{array}$ & $\begin{array}{c}\text { Positive } \\
(++)\end{array}$ & $\begin{array}{c}\text { Strong } \\
\text { Positive } \\
(+++)\end{array}$ & $\begin{array}{c}\text { Very Strong } \\
\text { Positive } \\
(++++)\end{array}$ & Total \\
\hline Alkaloid & 7 & 3 & 7 & 3 & 0 & 20 \\
Flavonoid & 5 & 7 & 6 & 2 & 2 & 20 \\
Triterpenoid & 5 & 11 & 3 & 1 & 0 & 20 \\
Steroid & 0 & 4 & 4 & 12 & 0 & 20 \\
Tanin & 2 & 13 & 4 & 0 & 0 & 20 \\
Saponin & 6 & 4 & 10 & 0 & 0 & 20 \\
\hline
\end{tabular}

\section{a. Alkaloids}

Alkaloid is a class of the largest compounds secondary plant substances. Nowadays, this has 
been known as 5, 500 alkaloid. This often poisonous for humans and have many physiological activities that stand out widely in the medical field, especially inhibit the growth of cancer cells (Gailea 2005).

\section{b. Flavonoids}

Flavonoids derived from the Latin word flavus meaning yellow same as its natural color. Flavonoids are plant secondary metabolites which have antioxidants and the significant chelates. Chemically, it is contained of 15 carbon skeleton which has two phenyl rings and a heterocyclic ring. More than 2000 flavonoid of plant have been identified but there are three general groups that is studied, such as anthocyanins, flavonols and flavones. In general flavonoid has three functions, there area antioxidants, metal binding and helps cell signaling.

Ginger and turmeric, both belonging to the family of Zingiberaceae is a plant species that has a very powerful flavonoid. It is used to treat skin diseases such as scabies and symptoms of leprosy. Gailea (2005) states that flavonoids may also use to treat liver dysfunction, decrease platelet aggregates (reduces blood clotting), anti-hypertensive and stimulate the growth of estrogen.

\section{c. Triterpenoids}

One of species plants is containing triterpenoids indicated a strong positive is the cinnamon (Cinnamomun burmanii) of the family Lauraceae. Triterpenoids are found in higher level plants. The abundant source of terpenoids is essential oils. Triterpenoid in the treatment have special quality as anti-inflammatory and gastroprotektor. While terpenes have anti-bacterial activity. A wide variety of physiological activities of various triterpenoids are active component in the medicinal plants that used for diabetes, antitumor (due to the effects of its cytotoxic), menstrual disorders, beak snake, skin disorders and malaria.

\section{d. Steroids}

The types of plants that contain of steroid elements has spread evenly. From the 20 species of plants, 12 species indicated strong positive, 4 species are positive and four species are not indicated. The use of plants that contain steroids are to treat tuberculosis, new wounds, cough, fever, asthma postpartum, heart disease, gout, breast cancer, malaria, constipation, dandruff, cholera, rabies, phlegm, scabies symptoms of leprosy, headaches, hypertension and toothache.

Steroids are commonly used in a variety of biological activities, such as to the development and control the reproduction of humans (estradiol, progesterone, testosterone), the purpose of Insecta (ecdysone) and early reproduction in fungi water (antheridiol). Steroid in the treatment application is used as a cardiotonic (digistoxin), a precursor of vitamin D (ergosteron), antiinflamantori (corticosteroid), oral contraceptives agent (semisynthetic estrogens and progestins) and anabolic agents (androgens) (Gailea 2005).

\section{e. Tanins}

The types of medicinal plants which contain tannins with positive indications as many as 12 
species. Tannins can be extracted from various plants such as leaves, bark, fruit, seeds, stem bark and other parts. Tannins' function for plants is to protect theirself. Tannins are useful as an astringent (fever) and is known as hemorrhoidal product, used as a treatment due to stinging insects and dental care.

\section{f. Saponins}

No one of pelak plants Kerinci community containing saponin with strong positive very strong positive indication. There are six species of negative saponin indications, 4 species indicated weak positive and 10 species indicated positive. Saponins in knowledge can be used as an antimicrobial material and can also be used as a poison and in the soap industry. While the use of saponin itself for the plant is as a defense, the protection of a wide range of biological effect.

Based on the identification and phytochemical studies of plants, 20 species from 27 pelak plant species is a plant with a function as a medicinal plant. This shows that local Kerinci community has their own knowledge of traditional medicine that proven scientifically.

Purwanto (2004), for the Indonesian community in isolated rural areas and living in the surrounding forest then the utilization of medicinal plants for the benefit of his health is not new thing, but it has happened for long time ago. It was also stated that each tribe has a specificity in the gathering and use the plants as medicine and herbs, it depends on the level of cultural and environmental resources of the surrounding nature.

Zuhud (2007) also stated that in various parts of the world, the disease and its treatment already has a typical system, different from each other, the nature and diversity of a judgment in match with the place (natural resources and human culture), the time and circumstances. In the atmosphere of the disease and its treatment has been the character of the nation.

\subsection{The Benefit of Pelak Plants as the Material of Natural Medication}

Based on the result of identification and photochemistry plants, 20 kinds out of 27 plants species of pelak are plants with medicinal function. It is shown that local society has the knowledge of traditional medication which is proved scientifically.

Purwanto (2004) stated that for Indonesian society in rural area, remote and live around the jungle using the medicinal plant for their health benefit is not new for them. It has been done since a long time ago. Next, it is mentioned that every Indonesian tribes has their own specialty in composing and using the plants as the medicinal and traditional thing. It depends on their culture and natural resources environment around them.

\section{1). Cinnamon (Cinnamomun burmanii Nees.)}

Cinnamon which has the scientific name Cinnamomun burmanii belonging to the family Lauraceae, is a long-lived plant species ( \pm 25 years) producing bark is used as a spice that is very flavorful, sweet and spicy.

Kerinci community take advantage of cinnamon, besides seasoning food, is also used as an antiseptic because of having volatile that has the power to kill the microorganisms. From the 
research, essential oils of cinnamon can kill bacilli thypus in just 12 minutes, while the oil of cloves needs 25 minutes. Essential oils can be used as a cure dysentery, cure rheumatism, diarrhea, colds, intestinal pain, heart, kidneys and high blood pressure. The other benefits of cinnamon oil is having the effect to remove the wind and appetizing or strengthen the stomach. Besides the oil can be used in industry as a mouthwash and pasta, freshener scent soaps, detergents, lotions, perfumes and cream. For food and beverage processing, cinnamon oil is used as a fragrance and flavor enhancers cake / food (curry and soup), soft drinks aroma (soft drinks) and liquor.

\section{2). Coffee (Coffea arabica L.)}

Coffee or by Kerinci community well known as 'kawa' belonging to the family Rubiacea is a herbaceous plant with a height up of to 2 to 3 meters. The seeds are shaped almost a half circle to elliptic, dorsally convex, flat stomach contained in the longitudinal grooves, dark brown to dark -black brown.

Based on the results of the research on Kerinci community shows that they already have knowledge of the cultivation and utilization of coffee. Cultivation of this plant has long done and for generations on their farm acreage agroforestry system called 'pelak'. In planting coffee, they usually do coincide with cinnamon seeded Kerinci community. Agroforestry Kerinci community has long existed, known as fields and pelak. The fields are agroforestry systems with the cycle of cultivation of trees alternate with seasonal plants, while pelak is a agroforestry complex systems with the main component of cinnamon or coffee, combined with various forest trees species from the forest.

The stages of pelak or fields activities are :

(1) During the first two years, annual crops are planted gather with coffe and cinnamon,

(2) Generally, Coffee produce is up to about eight years, after that years the farmers have three options that produce three systems: (a) System 1 (field), cinnamon cut and harvested, coffee trimmed short and annual crops are planted so that the system back to phase 1; (b) System 2 (fields): cinnamon continuously maintained and cared until about the 25th, cinnamon cut and harvested, then the system back to stage 1; (c) System 3 (pelak) that the types of useful trees that have been planted or growing spontaneously during phase 1 and 2 maintained together with cinnamon so that the system becomes a permanent mixed farms or agro-forestry pelak

Based on the interviews with interviewees mention that the coffee is used as a headache drug, relief of pain in the chest, detoxifying, fever, stomach pains, dysentery of drugs lower blood pressure. They make coffee as a medicine of stomach pains and headaches by one cup of coffee beans that have been washed and finely ground and then boiled with 2 cups water until the remaining $3 / 4$ then drink while warm. Getting treatment for the relief of pain in the chest is to boil 1 cup of coffee beans with 6 cups of water to the remaining 1/2, then after a lukewarm drink it. Coffee as medicine has long been used by Kerinci community and hereditary.

\section{3). Ginger (Zingiber officinale Roxb)}


Ginger known as 'spadeh' by Kerinci community, is a type of plant that is already known well because they usually use it for cooking spices. The characteristic of organoleptic and empirical benefits of ginger is aromatic smell, taste of refreshing spicy, warm and slightly bitter; increased appetite (tonic) and eliminates cough (ekspektoransia).

Organoleptic chaacteristic of ginger are aromatic smell, taste of refreshing spicy, warm and slightly bitter, improve appetite and relieve cough. Based on the results of the research on Kerinci community shows that they already have a knowledge of ginger's uses as a medicine. They use ginger to relieve colds, increase appetite, treat injuries and low back pain. The way how to use ginger to treat an infection is with a few slices of ginger rhizome that washed and shredded, then that scarped is wrapped in a piece of cloth and compress it on the wound infection. How to use is usually 2 times daily as needed. While for eliminating the headache is by taking a piece of ginger that has washed out and hit in its edges until the fibers are separated and resembles like a brush, then the rhizomes dipped in klonyo oil. After that, it can be used to rub his back, neck and temples. How to use is 1-2 times daily or as needed.

\section{4). Durian (Durio zibethinus Murr)}

Based on the results of research in the field showed that Kerinci community know durian is useful as a secondary food crops (source fruits) and can be used as medicine Cantengan pain and reduce fever. People use durian leaves for Cantengan sick by 5-10 leaves of fresh durian washed and finely ground, then put it on the sore body part. To reduce fever, by taking one finger of durian root then washed and finely ground, then knead it to exit the liquid. After that, it can be used as a liniment on the forehead or it could be also boiled for drinking.

\section{5). Mangosteen (Garcinia mangostama $\mathrm{L}$ )}

Based on interviews with interviewees mention that the mangosteen can be used as medicine for diarrhea by boiling the mangosteen rind that has washed with 2 cups water until $1 / 2$, and then drunk it. Organoleptic characteristic of the mangosteen is noticeably chelate leaves, bitter and slimy.

\section{6). Potato (Solanum tuberosum L.)}

Potato plants have long cultivated exclusively by Kerinci community. The cultivation has done because the potato has high enough commercial value. The cultivation has done with bulbs. Seed tubers can be used intact bulbs or tubers pieces that have buds.

Based on the results of the research show that Kerinci community is already have knowledge of the potatoes cultivation. This is proofed by looking the results of good potato, Kerinci community's potato has a good quality with a water content that fits. Besides having it as food, potatoes are also known as medicine by Kerinci community. Potatoes are used for medicinal bleeding gums, burns scare, diabetes and anemia. For the treatment of bleeding gums, potato tubers peeled and washed and cut into pieces as needed, then boiled in 4 cups water until the remaining $1 / 2$. After it is cooled and filtered, the water is used to rinse your mouth for 1 minute and swallowed. While for burns, tubers of potatoes are peeled, washed and finely ground, then knead with the addition of 1 teaspoon of coconut oil, then stir until 
evenly distributed, put on the body part that affected by burns, then wrapped with a clean cloth.

Potatoes are a drug for patients who have diabetes in a way 2-3 potatoes tuber are peeled and washed, cut into pieces as needed, then boiled in 4 cups water until the remaining $1 / 2$. After it, cooled and filtered, the water is drink and the potato tubers is eaten.

\section{7). Maize (Zea mays L.)}

Based on the interviews with interviewees indicated that the Kerinci community's knowledge of the cultivation of maize has been good enough. They planted corn in the field that usually performed as an interlude in a waiting for period to go to the field for the next season. Propagation of corn is doing with seed, then make holes for the plants by using a piece of bamboo (dibble $=$ ponjo). Tugal (a wood stick that used to make hole in the ground for palnting a seed) is plugged into the ground in suitable with the planting distance, depth of hole adapted to soil moisture. One week after planting if the plant is not growing, we can do stitching. The maintenance required is fertilizing, weeding and regulation of irrigation / water management. Corn harvesting can be done at the age of 100-120 days, but corncobs can be picked when still young to be consumed as fresh vegetables.

Organoleptic characteristic and pharmacology effects of corn is sweet, somewhat chelate, aromatic smell, neutral, entered the large intestine meridian and stomach, harmonize organs of central, increased appetite (tonic), strengthen the lungs, neutralizing heart, shed urine (diuretic), strengthens the spleen, removes heat, neutralize liver and bile launch expenses.

Kerinci community have been using corn as a cure diabetes and diarrhea. For the treatment of diarrhea with drying 1 corncob until dry up and then finely ground into powder. Two tablespoons of powder and then brewed with hot water and sugar as needed and then drink while warm. To treat diabetes, corn is used as an herb with other herbs which is weeds, tea plants and palm sugar and then boiled it in 3 cups of water until the remaining $3 / 4$. After that, it is filtered, chilled and drunk.

Based on the identification of agro-forestry plant 'pelak' this Kerinci community shows that most types of plant is useful as a medicinal plant. Purwanto (2004), for the Indonesian people in isolated rural areas and living in the surrounding forest then the utilization of medicinal plants for the benefit of his health is not new thing, but it has happened for long time ago. It was also stated that each tribe has a specificity in the gathering and use the plants as medicine and herbs, it depends on the level of cultural and environmental resources of the surrounding nature. Zuhud (2007) also stated that in various parts of the world, the disease and its treatment already has a typical system, different from each other, the nature and diversity of a judgment in match with the place (natural resources and human culture), the time and circumstances. In the atmosphere of the disease and its treatment has been the character of the nation.

The tendency at this time shows how traditional treatment of Kerinci community use plant is began to change along with the progress of information, education improved, economic pressures, a growing of population, a new lifestyle, displacement of community and the belief 
that comes from outside. This makes knowledge of traditional medicine is feared will become increasingly scarce and even disappear from the Kerinci community, especially in the young generation.

The social changing rapidly and acculturation may affect local knowledge and interest in the use of plants as medicinal products so that the people will have the opportunity to change the local area values. It is estimated the impact of technological developments in the fields of pharmaceuticals and aspects of the ease of obtaining treatment using modern medicine. Supported by the practicality of the implementation of modern medicine and the availability of infrastructure resulting in a change of life style from traditional to modern lifestyle.

\section{Conclusion and Suggestion}

\subsection{Conclusion}

The result showed that Kerinci societies are now independent in fulfilling their daily needs through farming and have an adequate knowledge in medication by using medicinal plants. The choice of agroforestry called pelak is based on experience and knowledge heritage due to the natural and benefit stimulus that they get. These kinds of pelak plants have made the Kerinci's societies' income increase as well as helped them increasing their additional income by developing medicinal agro-industrial plants. Thus, this research can conclude some conclusions such as:

1. Agroforestry plants (pelak) which contain phytochemical in the medicinal plants with a high cultural value are cinnamons, coffee/kawa, ginger, durian, mangosteen, potato, and corn.

2. The custom of Kerinci's societies in using pelak plants besides as main product is also heritage as the natural medicinal plants such as:

a) Cinnamons as the medication for dysentery, rheumatic, diarrhea, flu, intestinal pain, heart disease, back pain, and high blood pressure.

b) Coffee is used as the medication for headache, pain reliever, antidote, fever, dysentery and low blood pressure.

c) Ginger is used to relieve colds, increasing appetite, wound and back pain.

d) Durian is used for fever.

e) Mangosteen is for diarrhea.

f) Potati is used for bleeding gum, burns, diabetic, and blood problems.

g) Corn is used for diarrhea and disbetic.

\subsection{Suggestions}

Kerinci communities who have income from pelak plant in effort to increase the family income of some the cinnamon plant as a main crop. Additional income by doing diversification in plants that contain medicines ingredients such as cinnamon, coffee/ kawa, ginger, durian, mangosteen, potato and corn as natural medicines agro-industries in the 
village and regional governments may issue or e-regulation policies for the development of natural medicines plants of agro-industrial as superior of Kerinci community.

\section{Acknowledgements}

Aimed to Collage Directorate (Dikti) Kemendikbud RI that has funded this research through competitive grants to stage 2 in the year of 2015 and Dr. Asvic Helida as a member of the research. Then to the headman and the community of Keluru Keliling Danau sub-district Kerinci Regency Jambi Province who have helped in the process of collecting the data.

\section{References}

Ahmad Suryana, et al. (1995). Diversifikasi Pertanian. Dalam Proses Mempercepat Laju Pembangunan Nasional. Pustaka Sinar Harapan. Jakarta.

Aumeeruddy, Y. (2000). Pelak di Kerinci Jambi Dalam Ketika Kebun Berupa Hutan : Agroforest Khas Indonesia Sebuah Sumbangan Masyarakat. (p101 - 116). Bogor. Indonesia.

Aumeeruddy, Y, \& Bakels, J. (1994). Management of Sacred Forest in the Kerinci Valley Central Sumatra : An Example of Conservation of Biological Diversity and Its Cultural Basis . Journal d'Agric.Trad.et de Bota, Appl. XXXVI (2), 39 - 65.

Batubara, M.M dan Asvic Helidah. (2016). Agroforestry Natural and Benefits Stimuli for Improvement of Kerinci Community at Kerinci Seblat National Park (KNSP). Journal of Agricultural Studies, 4(3), 1-12.

Gailea, R. (2005). Identifikasi pemanfaatan dan Pengembangan Tumbuhan Obat di Sekitar Taman Nasional Lore Lindu (Tesis). Sekolah Pascasarjana IPB. Bogor. Tidak dipublikasikan.

Kartasubrata, J. (2003). Social Forestry dan Agroforestry di Indonesia. Lab Politik Ekonomi dan Sosial Kehutanan Fakultas Kehutanan Institut Pertanian Bogor. Buku I.

Michon, G. et al. (2000. Ketika Kebun Berupa Hutan : Agroforest Khas Indonesia Sebuah Sumbangan Masyarakat. International Centre For Research in Agroforestry . Bogor Indonesia

Purwanto, Y. (2004). Etnobotani Masyarakat Tanimbar-Kei Maluku Tenggara Sistem Pengetahuan dan Pemanfaatan Keanekaragaman Jenis Tumbuhan . Perhimpunan Masyarakat Etnobotani Indonesia Bogor Pustaka Penelitian Biologi LIPI

Purwanto, Y. (2007). Ethnobiologi, Ilmu Interdisipliner, Metodologi, Aplikasi dan Prosedurnya dalam Pengembangan Sumberdaya Tumbuhan. Bahan Kuliah Sekolah Pascasarjana IPB. Bogor.

Rudjiman, dkk. (2003). Buku Acuan Umum Tumbuhan Obat Indonesia Jilid I dan II. Kerjasama Fakultas Kehutanan Universitas Gadjah Mada dengan Yayasan Sarana Wana Jaya.

Turner, N. J. (1988). The Importance of a Rose : Evaluating The Cultural Significance of Plants in Thompson and Lillooet Interior Salish. Journal of American Anthropologist, 90, 272 -290 .

Zuhud, EAM. (2007). Sikap Masyarakat dan Konservasi Suatu Analisis Kedawung (Parkia 


\section{Macrothink}

Journal of Agricultural Studies

ISSN 2166-0379 2017, Vol. 5, No. 1

timoriana (DC) Merr.) Sebagai Stimulus Tumbuhan Obat Bagi Masyarakat, Kasus di Taman Nasional Meru Betiri. [Disertasi]. Bogor (ID) Sekolah Pasca Sarjana IPB.

\section{Copyright Disclaimer}

Copyright for this article is retained by the author(s), with first publication rights granted to the journal.

This is an open-access article distributed under the terms and conditions of the Creative Commons Attribution license (http://creativecommons.org/licenses/by/4.0/). 